\begin{tabular}{|l|l|l|}
\hline \multicolumn{2}{|c|}{ PublisherInfo } \\
\hline \hline PublisherName & $:$ & Palgrave Macmillan UK \\
\hline \hline PublisherLocation & $:$ & London \\
\hline \hline PublisherImprintName & $:$ & Palgrave Macmillan \\
\hline
\end{tabular}

\title{
Introduction of automatic occupation coding in ASHE
}

\begin{tabular}{|l|l|l||}
\hline \multicolumn{2}{|c|}{ ArticleInfo } \\
\hline \hline ArticleDOI & $:$ & 10.1057 /palgrave.elmr.1410122 \\
\hline \hline ArticleCategory & $:$ & Feature \\
\hline \hline ArticleFirstPage & $:$ & 29 \\
\hline \hline ArticleLastPage & $:$ & 32 \\
\hline \hline & & RegistrationDate $: 2007-8-17$ \\
ArticleHistory & $:$ & OnlineDate $\quad$ 2007-8-17 \\
\hline ArticleCopyright & $:$ & Crown copyright2007 \\
\hline \hline
\end{tabular}




\section{Describes the adoption of automatic coding by text recognition into} ASHE and the significant benefits that will ensue.

The automatic coding tool, automatic coding by text recognition (ACTR), is being introduced for the Annual Survey of Hours and Earnings (ASHE). ACTR has been shown to improve the quality of occupation coding. However, it also brings a moderate discontinuity in the ASHE results. The improvement in the quality of the coding, and the savings obtained from using ACTR, mean that the benefits of its adoption are significant. For continuity, a revised 2006 data set will also be created on an ACTR-coded basis.

\section{Misc}

The Full Text of this article can be found on the National Statistics website (http://www.statistics.gov.uk/elmr/08_07/downloads/ELMR08_07Scruton.pdf). 